\title{
Effect of Bio-Inoculants and Graded Level of Fertilizers on Nutrient Uptake in Garlic
}

\author{
Vikram Singh ${ }^{1,2 *}$, K.C. Sharma ${ }^{1}$ and H.R. Sharma ${ }^{2}$ \\ ${ }^{1}$ Krishi Vigyan Kendra, CSK Himachal Pradesh Krishi Vishvavidyalaya, Bajaura, \\ Kullu, Himachal Pradesh - 175125, India \\ ${ }^{2}$ Dr YS Parmar University of Horticulture and Forestry, Nauni, Solan, \\ Himachal Pradesh-173230, India \\ *Corresponding author
}

\section{A B S T R A C T}

\section{Keywords}

Bio-inoculants fertilizers,

Azotobacter, Garlic, Cloves, NPK, uptake.

Article Info

Accepted: 12 April 2017 Available Online: 10 May 2017
A field experiment was conducted during rabi season of 2014-15 to investigate the effect of different levels of bio- inoculants (Azotobacter and PSB) in combination with four levels of NPK fertilizers on yield and nutrient uptake of garlic cv. 'GHC-1'. The increased bulb yield was to the tune of $25.86 \%, 12.99 \%$ and $9.81 \%$ with the combination of bio- inoculants (Azotobacter + PSB), PSB and Azotobacter, respectively over un-inoculated control. The highest bulb yield $\left(20 \mathrm{t} \mathrm{ha}^{-1}\right)$ was recorded when the plots were supplemented with 100\% NPK + garlic cloves dipping of both the inoculants. The result further showed that Azotobacter and PSB $+100 \%$ RDF inorganic recorded higher nutrient uptake of NPK as compared to other treatment combinations. Bio-inoculants amendment in combination with synthetic fertilizers also improved the soil buildup over the initial soil status.

\section{Introduction}

Garlic (Allium sativum L.) is the second most important bulbous spice crop after onion widely used all over the world. The significance of this spice is increasing owing to its wide range of medicinal properties. Garlic is thought to have diaphoretic, expectorant, antispasmodic, antiseptic, bacteriostatic, antiviral, antihelminthic and hypotensive effects, it is commonly used to treat chronic bronchitis, recurrent upper respiratory tract infections and influenza. It is a rich source of vitamin $\mathrm{C}$, proteins, phosphorus, potash, calcium, magnesium and carbohydrates.
Generally, farmers use yard farm manure like cow, buffalo dung, poultry manure, and vermin compost as nutrient sources to crops supplement. But in these, nutrient supply is low and can only sustain low productivity of crops. The increasing need for enhanced productivity due to ever-increasing population necessitate high amount of nutrition. Organic form of nutrient constitutes a potential renewable source of nutrient supply to crops under all situations. Organic sources are relatively bulky materials and are added mainly to improve the physical condition of soil, to replenish and deep up its humus status and to maintain optimum condition for 
activities of soil microorganism. Organic manure has the capability of supplying a range of nutrients and improving the physical and biological properties of soil. However for getting higher yield, these nutrients are not adequate. Similarly, escalation in cost of chemical fertilizers, particularly that of $\mathrm{N}$, coupled with concerns about pollution have focused attention on the use of combined application of nutrients through organic and inorganic sources in crop production. Therefore, nutrient supply in crop system should be economically-viable, environmentfriendly and socially acceptable without affecting the gross plant production. It has been realized that soil fertility can be managed in complete harmony with sustainable agriculture development by careful analysis of current issues of sustainable land productivity (Saleh, 2008; Srinivasarao et al., 2008).

\section{Materials and Methods}

The present investigation was conducted at the Choudhary Sarwan Kumar Himachal Pradesh Krishi Vishvavidyalaya, Krishi Vigyan Kendra, Bajaura (Kullu), Himachal Pradesh during rabi season of 2014-2015, situated at $31^{\circ} 84^{\prime} 65^{\prime} \mathrm{N}$ latitude and $77^{\circ} 16^{\prime} 05^{\prime}$ ' $E$ longitude at an elevation of 1090 $\mathrm{m}$ above mean sea level. The experiment was consisted of 12 treatment combinations involving four levels of bio- inoculants (no inoculation, dipping of garlic cloves for 15 minutes in the culture of indigenous strain of Azotobacter, phosphorus solubilizing bacteria and Azotobacter + PSB) and three levels of N, $\mathrm{P}$ and $\mathrm{K}$ fertilizers $(50,75$ and $100 \%$ ) of the recommended dose of 125:75:60 kg ha $\left(\mathrm{N}: \mathrm{P}_{2} \mathrm{O}: \mathrm{K}_{2} \mathrm{O}\right)$ were evaluated in garlic variety GHC-1. The recommended dose of farmyard manure@ $20 \mathrm{t} \mathrm{ha}^{-1}$ was uniformly applied to all the treatment combinations. The full dose of $\mathrm{P}$ and $\mathrm{K}$ and half of $\mathrm{N}$ was applied through single super phosphate, muriate of potash and urea, respectively as per treatment combinations at the time of planting. The remaining $\mathrm{N}$ was top dressed in two equal splits at an interval of 30 and 60 days after planting. The experiment was laid out in a factorial randomized block design with three replications. Each plot $(2 \times 1.8 \mathrm{~m})$ consisted of ten rows with row to row and plant to plant spacing of $20 \mathrm{~cm}$ and $10 \mathrm{~cm}$, respectively. The initial composite soil sample $(0-15 \mathrm{~cm}$ depth) collected from the experimental site was analyzed for important soil physicalchemical characteristics using standard procedures and their values have been presented in table 1 .

\section{Results and Discussion}

\section{Bulb yield}

\section{Effect of biofertilizers}

A perusal of data revealed that significant differences were observed with the application of bio- inoculants applied either in mixture or alone over untreated control in table 2. The application of Azotobacter + PSB produced significantly the highest bulb yield of 18.59 tonnes per hectare followed by PSB (16.69 $\mathrm{t} \mathrm{ha}^{-1}$ ) and Azotobacter (16.22 $\left.\mathrm{t} \mathrm{ha}^{-1}\right)$. The application of Azotobacter + PSB, PSB and Azotobacter recorded an increased bulb yield of 25.86, 12.99 and 9.81 per cent, respectively over untreated control.

These results are in agreement with the findings of Chattoo et al., (2007) and Gowda et al., (2007) who found the beneficial effects of biofertilizers with 100 per cent recommended dose of chemical fertilizers for enhancing growth and yield of garlic. The increase in yield may be due to better root proliferation, more uptakes of nutrients and water, higher photosynthesis and enhanced food accumulation. The increase in yield was largely the consequence of cummulative 
effect of plant growth and yield characters viz., plant height, number of leaves per plant and different bulb characters like average bulb weight, diameter, clove weight and clove length. The findings are similar to those reported by Sharma et al., (2013) and Das et al., (2014) whom reported the improvement in growth and yield attributes in garlic with combined inoculation of biofertilizers in garlic.

\section{Effect of fertility levels}

An analysis of variance showed significant differences among the different fertility levels on bulb yield of garlic (Table 2). It was evident that bulb yield increased significantly and gradually with each increment in fertility levels from 50 to 100 per cent RDF (11.88 to $\left.20.11 \mathrm{t} \mathrm{ha}^{-1}\right)$. The application of 100 and 75 per cent RDF levels recorded an increased yield to the tune of 69.27 and 49.24 per cent over 50 per cent RDF level, respectively which could be ascribed to increase in yield attributes namely, bulb weight, diameter, number of cloves per bulb and clove weight and well developed root system that ultimately resulted in a healthy plant growth and in turn yield. Several workers had also exhibited enhanced growth, yield and its parameters in different crops with the application of graded levels of chemical fertilizers under varied agro climatic conditions (Choudhary et al., 2013; Sharma et al., 2013 and Assefa et al., 2015)

\section{Interaction effect}

An examination of data revealed that application of recommended dose of NPK + Azotobacter + PSB registered significantly the highest bulb yield (20.89 $\mathrm{t} \mathrm{ha}^{-1}$ ) compared to rest of the treatment combinations (Table 3). The application of Azotobacter + PSB, PSB and Azotobacter at 100 per cent fertility level recorded an increase in bulb yield to the tune of $8.85,4.68$ and 4.16 per cent, respectively over control. Further, it is pertinent to mention that the treatment combination comprising of 75 per cent recommended dose of NPK + Azotobacter + PSB performance at par with the recommended dose of NPK (100 $\%$ NPK) for bulb yield, thus resulting in a net saving of 25 per cent NPK fertilizers.

The increase in bulb yield could be due to higher and continuous availability of nutrients from combined source (Azotobacter + PSB + synthetic NPK nutrients) at vital growth period that might have enhanced the growth and yield parameter. This resulted in better photosynthetic activities of the plant that helped in better translocation of carbohydrates to the storage organs and ultimately enhanced biomass production (Sevak et al., 2012; Choudhary et al., 2013; Sharma et al., 2013; Das et al., 2014; Kumara et al., 2014 and Nainwal et al., 2015).

\section{Effect on nutrient uptake}

The data recorded on nitrogen, phosphorous and potassium by garlic plant (bulb + leaves \&stem) as influenced by the application of biofertilizers and different fertility levels after the harvest of garlic crop have been summarized in table 2 .

\section{Total nitrogen uptake}

\section{Effect of biofertilizers}

The seed cloves inoculated with Azotobacter + PSB recorded significantly maximum total nitrogen uptake $\left(89.80 \mathrm{~kg} \mathrm{ha}^{-1}\right)$ by garlic plant (bulb + leaves \&stem) followed by PSB (77.74 $\mathrm{kg} \mathrm{ha}^{-1}$ ) and Azotobacter $\left(75.06 \mathrm{~kg} \mathrm{ha}^{-}\right.$ $\left.{ }^{1}\right)$ compared to untreated control (Table 2). Significant differences between Azotobacter and PSB were also observed with respect to total $\mathrm{N}$ uptake. The higher $\mathrm{N}$ uptake with applied bio- inoculants might be due to the 
higher dry matter production as a result of better root proliferation, more photosynthesis, enhanced food accumulation in edible parts and nitrogen fixing ability of the inoculants. Similar observations have been reported by El-Desuki et al., (2006) in onion and Sharma et al., (2009) in cauliflower.

\section{Effect of fertility levels}

The analysis of variance showed significant differences among fertility levels with respect to total nitrogen uptake (Table 2). The results revealed that each increment in fertility levels from 50 to 100 per cent RDF increased significantly the total $\mathrm{N}$ uptake of garlic. The highest nitrogen uptake was recorded with 100 per cent RDF $(98.80 \mathrm{~kg})$ and lowest with 50 per cent RDF (42.27 kg) level. Similar findings were also reported by Zhang et al., (1998) and Damse et al., (2014) in garlic, who noted higher $\mathrm{N}$ uptake at 100 per cent RDF level. As nutrient uptake is a product of dry matter accumulation and nutrient content. Therefore, higher dry matter due to higher application of NPK fertilizers resulted in more dry matter accumulation hence, higher NPK uptake observed in the present study.

\section{Interaction effect}

The combined effect of biofertilizers and NPK application was found to be significant for total nitrogen uptake (Table 3). The results showed that the $\mathrm{N}$ uptake increased significantly with the application of bioinoculants integrated with increasing levels of RDF fertilizers. The application of 100 per cent RDF in combination with Azotobacter and PSB registered significantly the highest total nitrogen uptake $(112.57 \mathrm{~kg})$ as compared to rest of the combinations. Furthermore, it was observed that the differences between sole application of Azotobacter $(101.82 \mathrm{~kg} \mathrm{ha}$ $\left.{ }^{1}\right)$ and PSB (103.76 kg ha $\left.{ }^{-1}\right)$ at 100 per cent RDF level were statistically at par with each other for total $\mathrm{N}$ uptake. The increase in $\mathrm{N}$ uptake could be attributed to an adding supply of nutrients and well developed root system under balanced nutrient application resulting in better absorption of water and nutrients that resulted in an increase in dry matter as well as higher $\mathrm{N}, \mathrm{P}$ and $\mathrm{K}$ concentration in plants (Sharma et al., 2009).

\section{Total phosphorus uptake}

\section{Effect of biofertilizers}

The total uptake of phosphorus was significantly affected by different bioinoculants (Table 2). The highest phosphorus uptake was noticed in Azotobacter + PSB $(29.91 \mathrm{~kg})$ followed by PSB $(26.07 \mathrm{~kg})$ and Azotobacter $(24.74 \mathrm{~kg})$ thereby, showing the beneficial effect of biofertilizers. Similar reports were also documented by Damse et al (2014).

\section{Effect of fertility levels}

The analysis of variance indicated significant differences among the various RDF levels for total uptake of phosphorus (Table 2). The highest phosphorus uptake was recorded at 100 per cent RDF (33.19 kg) which was significantly superior over 75 per cent $(26.73$ $\mathrm{kg})$ and 50 per cent RDF $(15.51 \mathrm{~kg})$ levels. The increase in $\mathrm{P}$ uptake with the increasing fertility levels may be because of the increasing trend in the productivity and dry matter accumulation. These are essential nutrients and with increase in their level, the $\mathrm{P}$ uptake has also increased. Furthermore, the increased uptake may also be due to increase in root proliferation and other growth parameters (Ghanwat, 1998).

\section{Interaction effect}

The interaction effect of bio- inoculants and RDF levels was found to be significant for the total phosphorus uptake by garlic at harvesting (Table 3). The application of 100 
per cent RDF + Azotobacter + PSB registered significantly the highest phosphorus uptake $(37.79 \mathrm{~kg}$ ) compared to rest of the treatment combinations. Furthermore, it was also observed that the phosphorus uptake increased significantly with the application of PSB (35.09 kg ha ${ }^{-1}$ ) and Azotobacter (33.54 $\mathrm{kg} \mathrm{ha}^{-1}$ ) at 100 per cent RDF level over untreated control $(26.34 \mathrm{~kg})$ at same level of RDF (100\%). The increase in P uptake might be due to the synergy between biofertilizers and RDF. Similar results were also reported by Sharma et al., (2009) in cauliflower. .

Table.1 Initial soil characteristics

\begin{tabular}{|l|l|}
\hline Particulars & Content \\
\hline A. Mechanical analysis \\
\hline Sand (\%) & 22.6 \\
\hline Silt (\%) & 46.1 \\
\hline Clay (\%) & 30.2 \\
\hline Texture & Silt clay loam \\
\hline B. Chemical properties \\
\hline pH & 6.9 \\
\hline Organic carbon (\%) & 0.65 \\
\hline C. Available nutrient ${\left(\mathbf{k g ~ h a}^{-1}\right)}^{\mid}$ \\
\hline N & 266.20 \\
\hline P & 19.23 \\
\hline K & 246.00 \\
\hline
\end{tabular}

Table.2 Effect of bio- inoculants and NPK levels on nutrient uptake $\left(\mathrm{kg} \mathrm{ha}^{-1}\right)$ by garlic

\begin{tabular}{|l|c|c|c|c|c|c|c|}
\hline Treatment & $\begin{array}{c}\text { Bulb } \\
\text { Yield }\end{array}$ & $\begin{array}{c}\text { Total } \\
\text { Nitrogen }\end{array}$ & $\begin{array}{c}\text { Total } \\
\text { Phosphorus }\end{array}$ & $\begin{array}{c}\text { Total } \\
\text { Potassium }\end{array}$ & $\begin{array}{c}\text { Available } \\
\text { Nitrogen }\end{array}$ & $\begin{array}{l}\text { Available } \\
\text { Phosphorus }\end{array}$ & $\begin{array}{c}\text { Available } \\
\text { Potassium }\end{array}$ \\
\hline Biofertilizer \\
\hline Control & 14.77 & 57.80 & 19.85 & 27.44 & 260.31 & 18.59 & 240.45 \\
\hline Azotobacter & 16.22 & 75.06 & 24.74 & 33.11 & 281.83 & 20.76 & 258.81 \\
\hline PSB & 16.69 & 77.74 & 26.07 & 36.52 & 278.80 & 22.96 & 261.82 \\
\hline $\begin{array}{l}\text { Azotobacter } \\
\text { + PSB }\end{array}$ & 18.59 & 89.80 & 29.91 & 40.23 & 287.12 & 25.67 & 267.13 \\
\hline $\begin{array}{l}\text { CD } \\
\text { (P=0.05) }\end{array}$ & 0.39 & 1.59 & 0.75 & 0.85 & 4.83 & 0.42 & 4.88 \\
\hline \begin{tabular}{l} 
Fertility levels of recommended dose of NPK (\%) \\
\hline 50
\end{tabular} 111.88 & 57.80 & 19.85 & 27.44 & 265.48 & 19.54 & 244.99 \\
\hline 75 & 17.73 & 75.06 & 24.74 & 33.11 & 280.09 & 21.73 & 260.15 \\
\hline 100 & 20.11 & 77.74 & 26.07 & 36.52 & 284.97 & 24.34 & 264.65 \\
\hline $\begin{array}{l}\text { CD } \\
\text { (P=0.05) }\end{array}$ & 0.34 & 89.80 & 29.91 & 40.23 & 4.18 & 0.22 & 3.21 \\
\hline
\end{tabular}


Table.3 Interaction effects of bio- inoculants and NPK levels on nutrient uptake $\left(\mathrm{kg} \mathrm{ha}^{-1}\right)$ by garlic

\begin{tabular}{|c|c|c|c|}
\hline \multirow[t]{2}{*}{ Treatment } & \multicolumn{3}{|c|}{ Fertility levels of recommended NPK $(\%)$} \\
\hline & $\mathbf{5 0}$ & 75 & 100 \\
\hline \multicolumn{4}{|l|}{ Biofertilizers } \\
\hline \multicolumn{4}{|l|}{ Bulb Yield (kg ha $\left.{ }^{-1}\right)$} \\
\hline Control & 8.74 & 16.39 & 19.19 \\
\hline Azotobacter & 10.97 & 17.39 & 19.99 \\
\hline PSB & 12.41 & 17.59 & 20.09 \\
\hline Azotobacter + PSB & 15.39 & 19.49 & 20.89 \\
\hline $\mathrm{CD}(\mathrm{P}=0.05)$ & \multicolumn{3}{|c|}{0.64} \\
\hline \multicolumn{4}{|c|}{ Total nitrogen uptake $\left(\mathrm{kg} \mathrm{ha}^{-1}\right)$} \\
\hline Control & 33.10 & 63.25 & 77.05 \\
\hline Azotobacter & 44.64 & 78.71 & 101.82 \\
\hline PSB & 49.40 & 80.05 & 103.76 \\
\hline Azotobacter + PSB & 61.97 & 94.87 & 112.57 \\
\hline $\mathrm{CD}(\mathrm{P}=0.05)$ & \multicolumn{3}{|c|}{2.77} \\
\hline \multicolumn{4}{|c|}{ Total phosphorus uptake $\left(\mathrm{kg} \mathrm{ha}^{-1}\right)$} \\
\hline Control & 11.52 & 21.69 & 26.34 \\
\hline Azotobacter & 14.34 & 26.33 & 33.54 \\
\hline PSB & 16.14 & 26.99 & 35.09 \\
\hline Azotobacter + PSB & 20.02 & 31.90 & 37.79 \\
\hline $\mathrm{CD}(\mathrm{P}=0.05)$ & \multicolumn{3}{|c|}{1.30} \\
\hline \multicolumn{4}{|c|}{ Total potassium uptake $\left(\mathrm{kg} \mathrm{ha}^{-1}\right)$} \\
\hline Control & 16.33 & 28.60 & 37.39 \\
\hline Azotobacter & 21.43 & 32.45 & 45.45 \\
\hline PSB & 23.41 & 34.28 & 51.87 \\
\hline Azotobacter + PSB & 25.60 & 38.62 & 56.46 \\
\hline $\mathrm{CD}(\mathrm{P}=0.05)$ & \multicolumn{3}{|c|}{1.47} \\
\hline
\end{tabular}

\section{Total potassium uptake}

\section{Effect of biofertilizers}

Application of Azotobacter + PSB $(40.23 \mathrm{~kg})$ resulted in the highest total potassium uptake followed by PSB $(36.52 \mathrm{~kg})$ and Azotobacter $(33.11 \mathrm{~kg})$ in table 2 . The minimum uptake of phosphorus was recorded in untreated control $(27.44 \mathrm{~kg})$. Bio-inoculants have favourable influence on addition and accumulation of the nutrients as reported by Zhang et al., (1998).

\section{Effect of fertility levels}

The different doses of NPK fertilizers significantly influenced the total potassium uptake (Table 2). Application of 100 per cent RDF (47.79 kg) recorded significantly the highest total potassium uptake compared to 75 per cent RDF (33.49 kg) and 50 per cent RDF $(21.69 \mathrm{~kg})$. The results are in close proximity to the findings of Joshi et al., (1991) in mustard and Sharma et al., (2009) in cauliflower who observed higher $\mathrm{K}$ uptake at 100 percent fertility level. 


\section{Interaction effect}

Combined application of biofertilizers and NPK fertilizers (Table 3) significantly affected total potassium uptake by garlic plant (bulb + leaves \&stem). The treatment combination of Azotobacter + PSB + $100 \%$ RDF registered significantly the highest total potassium uptake $(56.46 \mathrm{~kg}$ ) as compared to rest of the treatments. Furthermore, it was observed that the total potassium uptake obtained with PSB (51.87 $\mathrm{kg})$ and Azotobacter $(45.45 \mathrm{~kg})$ at 100 per cent fertility level was also significant at same or different levels of fertility.

The balanced application of $\mathrm{N}$ at higher levels in combination with bio-inoculants might have favourably influenced the plant growth and development resulting in higher yield. Due to higher yield and dry matter accumulation, the crop removed larger quantities of nutrients (NPK) from soils. Such findings derive support from the work of many scientists elsewhere in country and abroad (Zhang et al., 1998 and Damse et al., 2014).

\section{Effect on soil properties}

The data recorded on available nitrogen, phosphorous and potassium content in soil as influenced by the application of bioinoculants and different fertility levels after the harvest of garlic crop have been summarized in table 2 .

\section{Available nitrogen}

\section{Effect of biofertilizers}

The build up of available nitrogen in soil was significantly influenced by application of bioinoculants (Table 2). Inoculation of garlic cloves with Azotobacter + PSB (287.12 kg ha ${ }^{1}$ ) resulted in significantly higher nitrogen content in soil after harvest but individually applied Azotobacter (281.83 kg ha ${ }^{-1}$ ) and PSB $\left(278.80 \mathrm{~kg} \mathrm{ha}^{-1}\right)$ remained at par but recorded significantly higher $\mathrm{N}$ build up over control $\left(260.31 \mathrm{~kg} \mathrm{ha}^{-1}\right)$. The increase in available $\mathrm{N}$ status due to biofertilizers application may be due to the multiplication of soil microbes leading to enhanced conversion of organically bound $\mathrm{N}$ into inorganic forms, rapid mineralization and thus made available to the crops (Miller et al., 1987; Kachroo and Razdan, 2006).

\section{Effect of fertility levels}

The application of 100 per cent RDF recorded significantly the maximum nitrogen build up $\left(284.97 \mathrm{~kg} \mathrm{ha}^{-1}\right)$ compared to 75 per cent RDF $\left(280.09 \mathrm{~kg} \mathrm{ha}^{-1}\right)$ and 50 per cent RDF (265.48 $\mathrm{kg} \mathrm{ha}^{-1}$ ) in table 2. Such an increase in available $\mathrm{N}$ due to applied chemical fertilizers had been recorded by many workers Jang et al., (1989) and Diriba et al., (2014). Katkar et al., (2012) had also reported higher build up of soil available $\mathrm{N}$ under integrated nutrient supply system.

\section{Available phosphorous}

\section{Effect of biofertilizers}

The available phosphorus status in soil after the harvest showed significant differences with the application of bio- inoculants (Table 2). The combined application of Azotobacter + PSB registered significantly the highest phosphorus build up in soil $\left(25.67 \mathrm{~kg} \mathrm{ha}^{-1}\right)$ compared to rest of the treatments. The differences between PSB $\left(22.96 \mathrm{~kg} \mathrm{ha}^{-1}\right)$ and Azotobacter $(20.76 \mathrm{~kg}$ ) were also significant, while the untreated control $\left(18.59 \mathrm{~kg} \mathrm{ha}^{-1}\right)$ recorded the minimum values. Biofertilizers produced various organic acids which solubilize phosphate and other phosphate bearing minerals thereby, increased $\mathrm{P}$ availability in soil (Tolanur and Badanur., 2003). 


\section{Effect of fertility levels}

Similarly, levels of NPK fertilizers revealed that phosphorus content in soil increased significantly with each increment in fertility levels from 50 to 100 per cent RDF (19.54 to $\left.24.34 \mathrm{~kg} \mathrm{ha}^{-1}\right)$ as presented in table 2 .

The higher soil P status with increasing levels of NPK coupled with biofertilizers might be due to lower utilization of $\mathrm{P}$ by the crop from applied sources, which resulted in building up of higher soil P status (Sharma et al., 2009).

\section{Available potassium}

\section{Effect of biofertilizers}

Significant differences were observed among bio- inoculants for available potassium build up in soil after the harvest of garlic (Table 2). The combined application of biofertilizers $($ Azotobacter + PSB $)$ registered significantly the maximum potassium build up in soil (267.13 kg ha $\mathrm{kg}^{-1}$ which was statistically superior over all other treatments. The sole application of PSB (261.82 $\left.\mathrm{kg} \mathrm{ha}^{-1}\right)$ and Azotobacter ( $258.81 \mathrm{~kg} \mathrm{ha}^{-1}$ ) remained at par with each other but recorded significantly higher potassium build up in soil compared to untreated control (240.45 kg ha ${ }^{-1}$ ) which indicated the beneficial effect of microbial inoculants. Rundala et al., (2012) also observed improvement in available nitrogen, phosphorus and potassium in soil due to seed inoculation with Azotobacter and PSB.

\section{Effect of fertility levels}

Similarly, the different doses of NPK significantly influenced the potassium build up in soil after harvest. The highest available potassium content in soil was recorded at 100 per cent RDF followed by 75 and 50 per cent $\mathrm{RDF}$ in table 2 . Increase in available $\mathrm{K}$ might be due to the direct addition to the available $\mathrm{K}$ pool of the soil, besides reduced K-fixation and release of $\mathrm{K}$ due to the interaction of organic matter with clay. Babar and Dongale (2011) also reported that available nitrogen, phosphorus and potassium in soil increased significantly with the application of organic, inorganic and their integration compared to control. Sharma et al., (2009) also observed similar findings in cauliflower.

In conclusion the increase in the uptake of nutrients $(\mathrm{N}, \mathrm{P}$ and $\mathrm{K})$ by garlic crop with integrated application of biofertilizers and NPK fertilizers is obvious as it is considered as a storehouse of plant nutrients, which provide optimum nutrients for crop. These results are in agreement with finding of Vachhani and Patel (1991). The higher uptake of nutrients under integrated nutrient management might also be due to added supply of nutrients and proliferous root system developed, resulting in more absorption of water and nutrients and adequate soil physical environment (Grewal and Trehan 1979; Miller et al., 1987).

\section{References}

Assefa, A.G., S.H. Mesgina and Abrha, Y.W. 2015. Effect of Inorganic and Organic Fertilizers on the Growth and Yield of Garlic Crop (Allium sativum L.) in Northern Ethiopia. J. Agri. Sci., 7: 4.

Babar, S., and Dongale, J.H. 2011. Soil fertility status as influenced by integrated nutrient management in mustard - cowpea - rice cropping sequence in lateritic soils of Konkan. An Asian J. Soil Sci., 6: 33-38.

Chattoo, M.A., N. Ahmed, S. Faheema, S. Narayan, S.H. Khan and Hussain, K. 2007. Response of garlic (Allium sativum L.) to biofertilizer Application. The Asian J. Horti., 2: 249-252.

Choudhary, B.S., A.K. Soni and Khaswan, S.L. 2013. Growth, yield and quality of 
garlic (Allium sativum L.) as influenced by different nutrient management practices. Annals of Agri. Res., 34: 210213.

Damse, D.N., M.N. Bhalekar and Pawar, P.K. 2014. Effect of integrated nutrient management on growth and yield of garlic. The Bioscan, 9: 1557-1560.

Das, S., M. Chanchan and Hore, J.K. 2014. Effect of inorganic and biofertilizer on growth and yield of garlic (Allium sativum L.). Res. Crops, 15: 912-915.

Diriba, S.G., D.R. Nigussie, K. Woldetsadik , G.Tabor and Sharma, J.J. 2014. Bulb quality of Garlic (Allium sativum L.) as influenced by the application of inorganic fertilizers. African J. Agri. Res., 9: 778-790.

EL-Desuki, M., R.M. Asmaa and Hafiz, M.M. 2006. Response of onion plants to minerals and biofertilizers application. Res. J. Agri. Biol. Sci., 2: 292-298.

Ghanwat, S.J. 1998. Effect of phosphorus application to soyabean on form $\mathrm{S}$ and $\mathrm{q} / \mathrm{I}$ relationship of $\mathrm{P}$ in an inceptisol. $\mathrm{M}$. Sc. Thesis, Mahatma Phule Krishi Vidyapeeth, Rahuri, India., p. 46.

Gowda, M.C., M. Vijayakumar and Gowda, A.P.M. 2007. Influence of integrated nutrient management on growth, yield and quality of garlic (Allium sativum L.) cv.G-282. Crop Res., 33: 144-147.

Grewal, J.S., and Trehan, S.P. 1979. Annual Scientific Report. Central Potato Research Institute, Shimla., p. 50-51.

Jang, B.G., J.H. Yoon and Park, J.K. 1989. The optimum levels of phosphate and potassium in the soil for garlic and radish. The research reports of the rural development administration (Korea, R.). Soil and Fertilizer, 31: 29-35.

Josi, A.J., R.P.S Ahlawat and Trivedi, S.J. 1991. Nitrogen concentration and uptake of mustard (Brassica juncea) as influenced by nitrogen and sulphur fertilization. Indian J. Agron., 36: 437-
439.

Kachroo, D., and Razdan, R. 2006. Growth, nutrient uptake and yield of wheat (Triticum aestivum) as influenced by biofertilizers and nitrogen. Indian $J$. Agron., 51: 37-39.

Katkar, R.N., V.K. Kharche, B.A. Sonune, R.H. Wanjari and Singh, M. 2012. Long-term effect of nutrient management on soil quality and sustainable productivity under sorghumwheat crop sequence in Vertisol of Akola, Maharashtra. Agropedol., 22: 103-114.

Kumara, B.R., Shankargoudapatil, P.M. Gangadharappa and Hegde, N.K. 2014. Effect of organic and inorganic sources of nitrogen on growth, yield and quality of garlic (Allium sativum L.). Trends in Biosci., 7: 1327-1330.

Miller, M.H., W.A. Mitchell, M. Stpya and Barry, D.A. 1987. Effects of nutrient availability and sub-soil bulk density on corn yield and nutrient absorption. Canadian J. Soil Sci., 67: 281-292.

Nainwal, R.C., D. Singh, R.S. Katiyar, L. Sharma and Tewari, S.K. 2015. Response of garlic to integrated nutrient management practices in a sodic soil of Uttar Pradesh, India. J. Spices and Aromatic Crops, 24: 33-36.

Rundala, S.R., B.L. Kumawat, G.L. Choudhary and Prajapat, K. 2012. Effect of integrated nutrient management on quality and nutrient uptake of Indian mustard (Brassica juncea L.) and after experimentation soil fertility. Environ. Ecol., 30: 15711575.

Saleh, J. 2008. Yield and chemical composition of 'Piarom' date palm as affected by levels and methods of iron fertilization, 2(3): 207-214.

Sevak, K., N.M. Patel, H.S. Bhadhauria and Wankhade, V.R. 2012. Effect of Integrated Nutrient Management on 
growth and yield of garlic (Allium sativum L.). Adv. Res. J. Crop Improvement, 3: 164-166.

Sharma, A., P. Kumar, D.K. Parmar, Y. Singh and Sharma, K.C. 2009. Effect of bioinoculants and graded level of fertilizer growth, yield and nutrient uptake in cauliflower (Brassica oleracea 1. var. botrytis 1). Vegetable Sci., 36: 344-348.

Sharma, K.C., L.K. Sharma, A.K. Sharma and Sharma, V. 2013. Response of biofertilizers and NPK levels on the growth and yield of garlic in North Western Himalayas. J. Hill Agri., 4: 5659.

Srinivasarao, C.H., S.P. Wani, K.L. Sahrawat, T.J. Rego and Pardhasaradhi, G. 2008. Zinc, boron and sulphur deficiencies are holding back the potential of rainfed crops in semi-arid India: Experiences from participatory watershed management, 2(1): 89-99.

Tolanur, S.I., and Badanur, V.P. 2003. Changes in organic carbon, available N, $\mathrm{P}$ and $\mathrm{K}$ under integrated use of organic manure, green manure and fertilizers on sustaining productivity of pearl milletpigeon pea system and fertility of an Incetisol. J. Indian Soc. Soil Sci., 51: 254-257.

Vachhani, M.U., and Patel, Z.G. 1991. Bulb yield quality of onion as influenced by levels of nitrogen, phosphorus and potash under south Gujrat condition. Progressive Horticulture, 23: 55-56.

Zhang, X., H.X. Zhu and Sum, C.H. 1998. Study on balanced fertilization and NPK nutrients absorption of garlic. Soils and Fertilizers, 1: 10-13.

\section{How to cite this article:}

Vikram Singh, K.C. Sharma and H.R. Sharma. 2017. Effect of Bio-Inoculants and Graded Level of Fertilizers on Nutrient Uptake in Garlic. Int.J.Curr.Microbiol.App.Sci. 6(5): 12001209. doi: https://doi.org/10.20546/ijcmas.2017.605.130 